\title{
Available Online at: http://ejournal.upbatam.ac.id/index.php/jim \\ ANALISIS KINERJA PEMUNGUTAN DAN RETRIBUSI PAJAK REKLAME TERHADAP PENDAPATAN ASLI DAERAH KOTA BATAM
}

\author{
Baru Harahap1, Syahril Effendi² \\ Universitas Putera Batam \\ baru@puterabatam.ac.id
}

\begin{abstract}
This study aims to find answers to the level of advertisement tax collection performance in the city of Batam, and its contribution to local tax revenue. This research applies a descriptive analysis method, The object of this study is Batam City. The sampling technique used is non-probability sampling, that is the technique of determining the sample using certain considerations or by using financial statements from 2015 to 2019. The results of hypothesis testing using multiple regression analysis methods show that the performance of the collection and retribution of advertisement tax levies on Batam City Dispenda has a significant effect on the local revenue. While partially the performance of collection on the Batam City Dispenda has a significant relationship to the original revenue of the region, however, advertisement tax levies have a significant effect on the region's original revenue on the Batam City.
\end{abstract}

Keywords: Collection Performance, Billboard Tax Levies Performance, Regional Original Revenue

\section{PENDAHULUAN}

Pajak merupakan salah satu sumber penerimaan utama bagi sebuah negara yang dibayarkan oleh masyarakat. Pajak juga sebagai iuran pemungutan yang dapat dipaksakan oleh pemerintah berdasarkan ketentuan peraturan perundang-undangan perpajakan serta sebagai perwujudan peran serta masyarakat atau wajib pajak untuk secara langsung dan bersama-sama melaksanakan kewajiban perpajakan yang diperlukan untuk pembiayaan negara dan pembangunan nasional.

Tujuan pembangunan nasional adalah untuk mewujudkan masyarakat yang adil dan makmur melalui peningkatan taraf hidup, kecerdasan dan kesejahteraan seluruh rakyat. Dalam pelaksanaan pembangunan nasional tersebut tidak terlepas oleh adanya pembangunan daerah. Sehingga untuk memperlancar pembangunan nasional diperlukan anggaran dari pemerintah negara yang diperoleh dari pemungutan pajak daerah. Untuk itulah pemerintah terus berupaya menggali setiap potensi yang bisa digunakan untuk meningkatkan dan mengoptimalkan penerimaan daerah.

Otonomi daerah merupakan suatu konsekuensi reformasi yang harus dihadapi oleh seluruh daerah di Indonesia. Oleh karena itu, dibutuhkan pembelajaran di setiap daerah untuk dapat mengubah tantangan menjadi sebuah peluang bagi kemajuan daerahnya. Disisi lain, pemerintah sebagai pengatur pengembangan konsep otonomi daerah, berperan sebagai penanggung jawab agar konsep otonomi daerah dapat dilaksanakan seperti yang diharapkan.

Adanya Undang-undang Nomor 28 Tahun 2009 tentang Pajak Daerah dan Retribusi Daerah dan Peraturan Daerah Kota Batam Nomor 12 Tahun 2008 tentang pokok-pokok pengelolaan keuangan daerah, membawa paradigma baru dalam pengelolaan daerah, dimana daerah diberikan kewenangan untuk mengelola sendiri kegiatannya yang meliputi: perencanaan, pelaksanaan, penatausahaan, pelaporan, pertanggungjawaban, dan pengawasan keuangan daerah. Atau dengan kata lain, daerah berhak mengatur sumber daya daerahnya untuk pencapaian perencanaan yang diharapkan. Dimana otonomi daerah memiliki peran sebagai upaya pemberdayaan daerah untuk mengambil keputusan sesuai dengan potensi dan kepentingan daerah itu sendiri.

Sehingga untuk melaksanakan otonomi daerah, pemerintah harus dapat mengidentifikasi sektor-sektor yang dinilai potensial sebagai pendorong pembangunan daerah, terutama melalui upaya peningkatan potensi Pendapatan Asli Daerah (PAD). 


\section{Available Online at: http://ejournal.upbatam.ac.id/index.php/jim}

Dimana kemampuan daerah dalam memaksimalkan Pendapatan Asli Daerah (PAD) dapat dilakukan melalui peran serta masyarakat dalam pembayaran pajak dan retribusi.

Perubahan berbagai kebijakan nasional sebagaimana dimaksud membawa harapan besar bagi daerah untuk membangun daerahnya dengan menggali potensi daerahnya masingmasing sebagai sumber pendapatan daerah, khususnya pendapatan asli daerah. Harapan dari daerah tersebut merupakan hal yang wajar, karena diberikannya berbagai urusan pemerintahan sebagai urusan rumah tangganya dibarengi dengan muatan kewenangan untuk mengurus keuangannya secara otonom dalam membiayai penyelenggaraan otonomi, baik dalam menggali sumber-sumber keuangan, pemanfaatannya serta pertanggungjawabannya.

Pendapatan Asli Daerah (PAD) merupakan pendapatan daerah yang bersumber dari hasil pajak daerah, retribusi daerah, pengelolaan kekayaan daerah dan lain-lain. Penyediaan pembiayaan dari pendapatan asli daerah dilakukan melalui peningkatan kinerja pemungutan, penyempurnaan, dan penambahan jenis retribusi, pajak daerah dan sumber pendapatan lainnya. Sehingga Pendapatan Asli Daerah (PAD) menjadi sangat penting karena berperan sebagai sumber pembiayaan dan sebagai tolak ukur dalam pelaksanaan otonomi daerah.

Kunci kemandirian daerah adalah pengelolaan Pendapatan Asli Daerah (PAD). Pajak daerah sebagai salah satu sumber Pendapatan Asli Daerah (PAD) diharapkan mampu memberikan kontribusi yang besar bagi daerah itu sendiri sehingga dapat memperlancar penyelenggaraan pemerintah dan pembangunan daerah. Sedangkan kemampuan keuangan daerah diukur dari besarnya kontribusi Pendapatan Asli Daerah (PAD) terhadap anggaran pendapatan daerah, dimana salah satu caranya yaitu dengan mengoptimalkan pajak daerah yang sudah ada.

Sebagai salah satu daerah otonom, Batam sudah seharusnya melaksanakan programprogram pembangunan baik program jangka pendek maupun jangka panjang. Untuk merealisasikan program pembangunan tersebut, pemerintah kota Batam berusaha untuk mengoptimalkan pendapatan daerah melalui pajak reklame. Karena apabila dilihat dari kontribusinya bagi pajak daerah, pajak reklame sebagai salah satu sumber Pendapatan Daerah yang berpotensi, dan dapat dilakukan pemungutan secara efisien, efektif, dan ekonomis sehingga dapat lebih berperan dalam usaha peningkatan Pendapatan Asli Daerah khususnya di Kota Batam.

Kekuatan APBD paling besar diperoleh dari potensi pajak daerah yang dapat terus ditingkatkan setiap tahunnya. Berlakunya Undang-undang No. 28 Tahun 2009 tentang Pajak Daerah dan Retribusi Daerah menjadi salah satu penyebab rendahnya pendapatan dari sektor pajak di Kota Batam.

Hingga akhir tahun anggaran 2015, perolehan pajak jauh dari yang diharapkan, dan salah satunya perolehan dari pajak reklame yang pendapatannya menurun drastis hingga 30 persen dari target awal. Disamping itu, pemerintah kota juga takut untuk membongkar paksa tiang dan papan reklame yang belum membayar pajak. Yang alasannya, masalah hukum dikemudian hari.

Banyaknya reklame yang tidak membayar pajak merupakan reklame yang berada didaerah milik jalan (damija) dan taman. Dimana reklame tersebut pungutan sewanya sulit ditarik dan banyak yang perizinannya sudah mati, namun masih berdiri tegak tanpa adanya tindakan dari pemerintah kota. Evaluasi perolehan pajak reklame pada Kota Batam hingga akhir tahun 2015 membuktikan persentasase pencapaiannya masih rendah, dan dinilai tidak memenuhi target perencanaan Pemerintah Kota. Dimana target pendapatan di awal APBD tahun anggaran 2015, antara realisasi dan pencapaiannya tidak sebanding.

Perolehan Pendapatan Asli Daerah (PAD) Kota Batam dari sektor pajak reklame ini memiliki potensi tinggi, karena tidak sedikit perorangan atau badan usaha yang menggunakan reklame sebagai alat untuk mempromosikan usahanya. Selain itu dalam pemungutan pajak reklame seharusnya tidak sulit, karena objek dan jumlah titiknya sudah jelas. Seharusnya pencapaian perolehan Pendapatan Asli Daerah (PAD) dari sektor ini dapat terpenuhi. Sehingga dengan mengoptimalkan kinerja pemungutan dari pajak reklame diharapkan dapat meningkatkan Pendapatan Asli Daerah (PAD) Kota Batam.

\section{TINJAUAN PUSTAKA \\ Kinerja Pemungutan}


Available Online at: http://ejournal.upbatam.ac.id/index.php/jim

Kinerja pemungutan pajak reklame di Indonesia saat ini didasarkan pada dasar hukum yang jelas dan kuat sehingga harus dipatuhi oleh masyarakat dan pihak terkait. Dasar hukum pemungutan pajak reklame pada suatu kabupaten/kota menurut Siahaan (2015: 325) adalah:

1. Undang-undang Nomor 34 Tahun 2000 yang merupakan perubahan atas Undangundang Nomor 18 Tahun 1997 tentang Pajak Daerah dan Retribusi Daerah.

2. Peraturan Pemerintah Nomor 65 Tahun 2001 tentang Pajak Daerah

3. Peraturan Daerah kabupaten/ kota yang mengatur tentang Pajak Reklame.

4. Keputusan bupati/walikota yang mengatur tentang Pajak Reklame sebagai aturan pelaksanaan peraturan daerah tentang Pajak Reklame pada kabupaten/kota dimaksud.Agar kinerja pemungutan pajak tidak menimbulkan hambatan atau perlawanan, maka pemungutan pajak harus memenuhi syarat (Mardiasmo, 2013: 2-3) sebagai berikut.

1.Pemungutan pajak harus adil (Syarat Keadilan)

Sesuai dengan tujuan hukum, yakni mencapai keadilan, undang-undang dan pelaksanaan pemungutan harus adil. Adil dalam perundang-undangan diantaranya mengenakan pajak secara umum dan merata, serta disesuaikan dengan kemampuan masingmasing. Sedangkan adil dalam pelaksanaannya yakni dengan memberikan hak bagi Wajib Pajak untuk mengajukan keberatan, penundaan dalam pembayaran dan mengajukan banding kepada Majelis Pertimbangan Pajak.

2.Pemungutan pajak harus berdasarkan undang-undang (Syarat Yuridis)

Di Indonesia, pajak diatur dalam UUD 1945 pasal 23 ayat 2. Hal ini memberikan jaminan hukum untuk menyatakan keadilan, baik bagi negara maupun warganya.

3.Tidak mengganggu perekonomian (Syarat Ekonomis)

Pemungutan tidak boleh mengganggu kelancaran kegiatan produksi maupun perdagangan, sehingga tidak menimbulkan kelesuan perekonomian masyarakat.

4.Pemungutan pajak harus efisien (Syarat Finansiil)
Sesuai fungsi budgetair, biaya pemungutan pajak harus dapat ditekan sehingga lebih rendah dari hasil pemungutannya.

5.Sistem pemungutan pajak harus sederhana

Sistem pemungutan yang sederhana akan memudahkan dan mendorong masyarakat dalam memenuhi kewajiban perpajakannya. Syarat ini telah dipenuhi oleh undang-undang perpajakan yang baru.

\section{Retribusi Pungutan Pajak Reklame}

Retribusi reklame merupakan salah satu Pendapatan Asli Daerah (PAD) Kota Batam dikelola oleh Dinas Pendapatan Daerah (PAD) Kota Batam. Pembangunan yang ada di Kota Batam merupakan tanggung jawab seluruh pihak Pemerintah, para pengusaha dan masyarkat yang membrikan dukungan kelancaran pembangunan tersebut.

Retribusi reklame dikenakan per tahun (1 Tahun), kecuali retribusi untuk jenis umbulumbul dikenakan per minggu ( 1 minggu), Perwako Pemerintah Kota Batam Nomor 24 Tahun 2011, Retribusi Ijin Penyelenggaraan Reklame adalah pungutan daerah sebagai pembayaran atas jasa pelayanan terhadap ijin pemasangan reklame di luar sarana prasarana kota.

Dalam pelaksanaan pemungutan retribusi reklame oleh Dinas Pendapatan Asli Daerah Kota Batam, yang mana telah ditentukan Peraturan Daerah Kota Batam (Perda) Nomor 5 Tahun 2009 tentang Retribusi Penggunaan Tanah dan/atau Bangunan Yang Dikuasai Pemerintah Daerah Untuk Pemasangan Reklame dalam Bab IV tentang Nama, Obyek, Subyek, dan Wajib Retribusi Pasal 6 yang berbunyi setiap orang dan/atau Badan Hukum yang menggunakan pemakaian tanah dan/atau bangunan yang dimiliki atau dikuasai oleh Pemerintah Daerah untuk pemsangan reklame dipungut retribusi dengan nama retribusi penggunaan tanah dan/atau bangunan yang dimiliki atau dikuasai oleh Pemerintah Daerah untuk pemasangan reklame.

\section{Pendapatan Asli Daerah (PAD)}

Pajak Daerah menurut Mardiasmo (2013:12) adalah iuran yang dilakukan oleh orang pribadi atau badan kepada daerah tanpa imbalan langsung yang seimbang, yang dapat dipaksakan berdasarkan peraturan perundangundangan yang berlaku, yang digunakan untuk membiyai penyelenggaraan pemerintah daerah. 


\section{Terakreditasi Nasional}

\section{Available Online at: http://ejournal.upbatam.ac.id/index.php/jim}

Pajak Daerah merupakan pajak yang ditetapkan oleh pemerintah daerah dengan peraturan daerah (Perda) yang wewenang pemungutannya dilaksanakan oleh pemerintah daerah dalam melaksanakan penyelenggaraan pemerintah dan pembangunan daerah.

Menurut Undang-undang Nomor 28 Tahun 2009, Peraturan Daerah Kota Batam Nomor 5 Tahun 2011 tentang Pajak Daerah. Yang dimaksud dengan Pajak Daerah yang selanjutnya disebut pajak adalah kontribusi wajib kepada daerah yang terutang oleh orang pribadi atau badan yang bersifat memaksa berdasarkan Undang-undang, dengan baik memdapatkan imbalan secara langsung dan digunakan untuk keperluan daerah bagi sebesar-sebesarnya kemakmuran rakyat.

Adapun jenis-jenis pajak daerah yaitu: Pajak Hotel; Pajak Restoran; Pajak Hiburan; Pajak Reklame; Pajak Penerangan Jalan; Pajak Pengambilan Bahan Galian Golongan C; Pajak Parkir; Pajak Air Tanah; Pajak Sarang Burung Walet; Pajak Bumi dan Bangunan Perdesaan dan Perkotaan; dan Bea Perolehan Hak atas Tanah dan Bangunan.

Pengertian Pendapatan Asli Daerah menurut Undang-undang Nomor 28 Tahun 2009 yaitu sumber keuangan daerah yang digali dari wilayah daerah yang bersangkutan yang terdiri dari hasil pajak daerah, hasil retribusi daerah, hasil pengelolaan kekayaan daerah yang dipisahkan dan lain-lain pendapatan asli daerah yang sah. Pendapatan Daerah adalah semua hak daerah yang diakui sebagai nilai kekayaan bersih dalam periode anggaran tertentu. Sesuai dengan Undang-undang Nomor 32 Tahun 2004 Tentang Pemerintah Daerah, bahwa daerah itu sendiri yaitu pendapatan asli daerah serta lain-lain pendapatan yang sah.

Menurut Adisasmita (2011: 89) Sistem pemerintahan daerah yang sentralilistik pada masa orde lama dan orde baru menimbulkan banyak dampak negative diantaranya adalah telah mengekang kreativitas daerah untuk mengembangkan potensi daerahnya sesuai dengan keinginan masyarakat daerah dan telah menyebabkan pemerintah daerah memiliki ketergantunganyang kuat terhadap pemerintahan pusat. Dengan kedua hal ini saja telahmembuat pemerintah daerah dan masyarakat lokal tidak mampu membangun daerahnya.

Untuk dapat melakukan pembangungan, pemerintahan daerah diharapkan dapat meningkatkan PAS untuk mengurangi keterntungan terhadap pembiayaan dari pusat, sehingga meningkatkan penerimaan daerahnya adalah menghitung potensi pendapatan asli daerah yang riil yang dimiliki.

Berdasarkan kajian teori di atas, kerangka berpikir dalam penelitian ini yang berjudul Pengaruh Kinerja Pemungutan Dan Retribusi Pungutan Pajak Reklame Terhadap Pendapatan Asli Daerah (PAD) Kota Batam. Untuk mempermudah dalam penelitian, peneliti menyusun bagan alur kerangka pemikiran sebagai berikut:

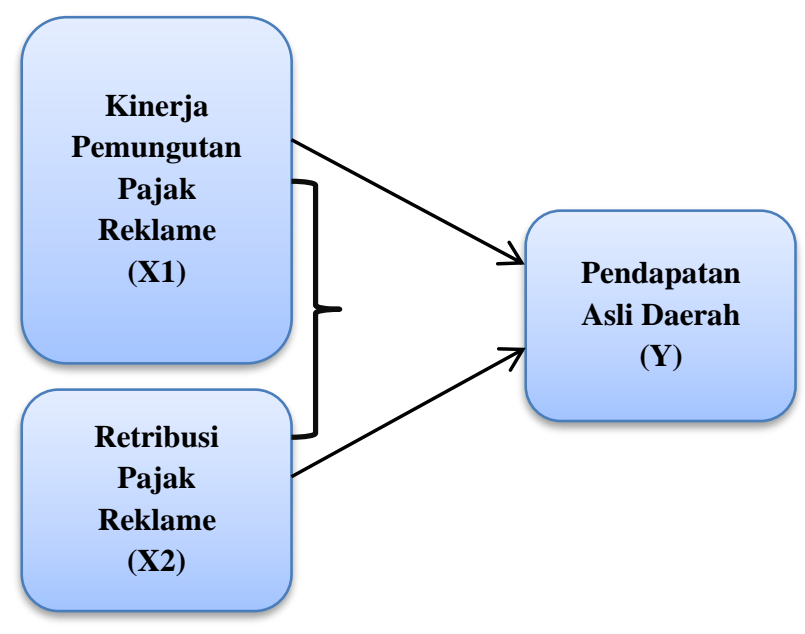

Gambar 1. Kerangka Berfikir Penelitian

Dari kerangka pemikiran yang telah di jelaskan pada sub bab sebelumnya yang menjurus pada hipotesis dapat disimpulkan bahwa hipotesis yang di dapat ialah sebagai berikut:

H1: Diduga ada hubungan kinerja pemungutan pajak reklame terhadap pendapatan asli daerah (PAD).

H2: Diduga ada hubungan retribusi pajak reklame terhadap Pendapatan Asli Daerah (PAD).

H3: Diduga ada pengaruh kinerja pemungutan pajak reklame dan retribusi reklame terhadap pendapatan asli daerah (PAD).

\section{METODOLOGI PENELITIAN}

Penelitian adalah suatu proses mencari sesuatu secara sistematik dalam waktu yang lama dengan menggunakan metode ilmiah serta aturan-aturan yang berlaku. Untuk dapat menghasilkan suatu penelitian yang baik, maka peneliti bukan hanya mengetahui aturan permainan, tetapi juga harus mempunyai 


\section{Terakreditasi Nasional}

Available Online at: http://ejournal.upbatam.ac.id/index.php/jim

keterampilan-keterampilan dalam melaksanakan penelitian. Untuk menerapkan metode ilmiah dalam praktek penelitian, maka diperlukan suatu desain penelitian, yang sesuai dengan kondisi, seimbang dengan penelitian yang dikerjakan(Nazir, 2014: 70).

Desain penelitian merupakan suatu rencana kerja yang terstruktur dalam hal hubungan - hubungan antar variabel secara komprehensif, sedemkian rupa agar hasil risetnya dapat memberikan jawaban atas pertanyaan - pertanyaan riset. Dalam rencana tersebut mencakup hal - hal yang akan dilakukan periset mulai dari membuat hipotesis dan implikasinya secara operasional sampai pada analisis terakhir (Umar,2010:5)

Proses perencanaan penelitian dimulai dari identifikasi, pemilihan serta rumusan masalah, sampai dengan perumusan hipotesis serta kaitannya dengan teori dan kepustakaan yang ada (Nazir, 2014: 70-71). Sampel penelitian Laporan keuangan yang berupa target penerimaan,realisasi penerimaan pajak reklame dan penerimaan Pendapatan Asli Daerah Kota Batam tahun 2015-2019. Metode analisis yang digunakan adalah persamaan Regersi Linear

Berganda $Y=a+b_{1} X_{1}+b_{2} X_{2}+\varepsilon$.

Keterangan:

$\mathrm{Y} \quad=$ Pendapatan Asli Daerah

$\mathrm{A} \quad=$ Konstanta persamaan regresi

$\mathrm{b}_{1}, \quad=$ Koefisien regresi

$\mathrm{b}_{2}, \mathrm{~b}_{3}$

Tabel 1. Hasil Analisis Regresi Linear Berganda

Coefficients $^{\mathrm{a}}$

\begin{tabular}{|ll|r|r|r|}
\hline \multirow{2}{*}{ Model } & \multicolumn{2}{|c|}{ Unstandardized Coefficients } & Standardized Coefficients \\
\cline { 2 - 5 } & \multicolumn{1}{|c|}{ B } & \multicolumn{1}{c|}{ Std. Error } & \multicolumn{1}{c|}{ Beta } \\
\hline \multirow{3}{*}{1} & (Constant) & $\mathbf{3 6 5 3 1 8 2 2 4 . 7 6 8}$ & 65650006.329 & \\
\\
X1 & $\mathbf{. 2 6 2}$ & .058 & .438 \\
X2 & $\mathbf{. 3 0 9}$ & .063 & .478 \\
\hline
\end{tabular}

a. Dependent Variable: Y

Sumber: Output SPSS Versi 20 (2019)

Dari tabel 1 hasil uji regresi linier berganda diatas maka diperoleh persamaan regresi linier berganda sebagai berikut:

$$
\begin{aligned}
& Y=a+b_{1} x_{1}+b_{2} x_{2} \\
& Y=365318224.768+(0.262) X_{1}+
\end{aligned}
$$

(0.309) $\mathrm{X}_{2}$

Keterangan:

$\mathrm{Y}=$ Pendapatan Asli Daerah $(\mathrm{Y})$

$\mathrm{a}=$ konstanta

$\mathrm{b}_{1}=$ koefisien regresi $_{1}$

$\mathrm{X}_{1}=$ Kinerja Pemungutan Pajak Reklame (X1)

$\begin{array}{lll}\mathrm{X}_{1} & =\text { Kinerja Pemungutan } \\ \mathrm{X}_{2} & =\quad \text { Retribusi Pungutan Pajak } \\ & \text { Reklame } \\ \mathrm{e} & =\text { Epsilon }\end{array}$

Rancangan Hipotsis adalah Kinerja Pemungutan dan Retribusi Pungutan Pajak Reklame berpengaruh Pendapatan Asli Daerah (PAD) secara baik secara parsial maupun secara simultan Kota Batam.

- $\mathrm{HO}=$ Kinerja Pemungutan dan Retribusi Pungutan Pajak Reklame tidak berpengaruh Pendapatan Asli Daerah (PAD) secara baik secara parsial maupun secara simultan.

- $\mathrm{H} 1$ = Kinerja Pemungutan dan Retribusi Pungutan Pajak Reklame berpengaruh Pendapatan Asli Daerah (PAD) secara baik secara parsial maupun secara simultan.

\section{HASIL DAN PEMBAHASAN}

\section{Analisis Regresi Linear Berganda}

Dalam analisis regresi, selain mengukur kekuatan hubungan antara tiga variabel atau lebih, juga menunjukan arah hubungan antara variabel dependen dengan variabel independen. Variabel independen pada penelitian ini yaitu Kinerja Pemungutan Pajak Reklame (X1) dan Pungutan Retribusi Pajak Reklame (X2) terhadap variabel dependen yaitu Pendapatan Asli Daerah (Y). Berikut ini tabel 1 adalah hasil uji dari analisis regresi linear berganda:
$\mathrm{B}_{2}=$ koefisien regresi 2

$\mathrm{X}_{2}=$ Pungutan Retribusi Pajak Reklame (X2) Persamaan regresi tersebut dapat diuraikan sebagai berikut:

$\alpha=365318224.768$ artinya jika nilai Kinerja Pemungutan Pajak Reklame (X1) dan Pungutan Retribusi Pajak Reklame (X2) sama dengan nol, maka nilai profitabilitas sebesar 365318224.768.

$b_{1}=$ Nilai koefisien regresi variabel Kinerja Pemungutan Pajak Reklame (X1) 


\section{Available Online at: http://ejournal.upbatam.ac.id/index.php/jim}

sebesar 0.262 artinya jika Kinerja Pemungutan Pajak Reklame (X1) mengalami peningkatan 1 kali, maka Pendapatan Asli Daerah (Y) akan mengalami kenaikan sebesar 0.262 dengan asumsi variabel lainnya konstan. Nilai koefisien positif artinya terjadi hubungan positif dan memiliki arah yang sama antara Kinerja Pemungutan Pajak Reklame (X1) dan Pendapatan Asli Daerah (Y).

$\mathrm{b}_{2}=$ Koefisien regresi variabel Pungutan Retribusi Pajak Reklame (X2) sebesar 0.309 artinya jika Pungutan Retribusi Pajak Reklame (X2) mengalami peningkatan 1 kali, maka profitabilitas akan mengalami penurunan sebesar 0.309 dengan asumsi variabel lainnya

\section{Terakreditasi Nasional}

konstan. Nilai koefisien positif artinya terjadi hubungan positif dan memiliki arah berlawanan antara Pungutan Retribusi Pajak Reklame (X2) dan Pendapatan Asli Daerah (Y).

\section{Hasil Pengujian Hipotesis}

Pengujian hipotesis dalam penelitian ini dilakukan dengan menggunakan model uji koefisien determinasi, uji statistik t, uji statistik $\mathrm{F}$ dan analisis regresi linier berganda (multiple regression analysis).

Koefisien Determinasi

Uji koefisien determinasi dilakukan untuk mengukur kemampuan variabel independen dalam menjelaskan variabel dependen. Adapun hasil uji koefisien determinasi dapat dilihat dalam tabel 2.

Tabel 2. Hasil Uji Koefisien Determinasi

Model Summary ${ }^{b}$

\begin{tabular}{|l|r|r|r|r|}
\hline Model & \multicolumn{1}{|c|}{$\mathrm{R}$} & \multicolumn{1}{c|}{ R Square } & \multicolumn{1}{c|}{$\begin{array}{c}\text { Adjusted R } \\
\text { Square }\end{array}$} & Std. Error of the Estimate \\
\hline 1 & $.834^{\mathrm{a}}$ & .695 & $\mathbf{. 6 8 4}$ & 213463287.719 \\
\hline
\end{tabular}

a. Predictors: (Constant), X2, X1

b. Dependent Variable: Y

Sumber: Output SPSS Versi 20 (2019)

Hasil uji koefisien determinasi pada tabel

2 menunjukan nilai Adjusted $R$ Square (Adjusted $R^{2}$ ) sebesar 0.684 atau sebesar $68.4 \%$.

Nilai ini menunjukkan bahwa variabel Pendapatan Asli Daerah (Y) dapat dijelaskan atau dipengaruhi hanya $68.4 \%$ oleh Kinerja Pemungutan Pajak Reklame (X1) dan Pungutan Retribusi Pajak Reklame (X2), sedangkan sisanya $31.6 \%(100 \%-68.4 \%)$ dijelaskan atau

dipengaruhi oleh faktor-faktor lain yang tidak disertakan dalam model penelitian ini.

\section{Hasil Uji T}

Uji Statistik t digunakan untuk mengetahui ada atau tidaknya pengaruh masing-masing variabel independen secara parsial terhadap variabel dependen yang diuji pada tingkat signifikansi 0,05 . Hasil uji t dalam penelitian ini ditunjukkan dalam tabel 3 dibawah ini:

\section{Tabel 3. Hasil Uji T}

Coefficients $^{\mathrm{a}}$

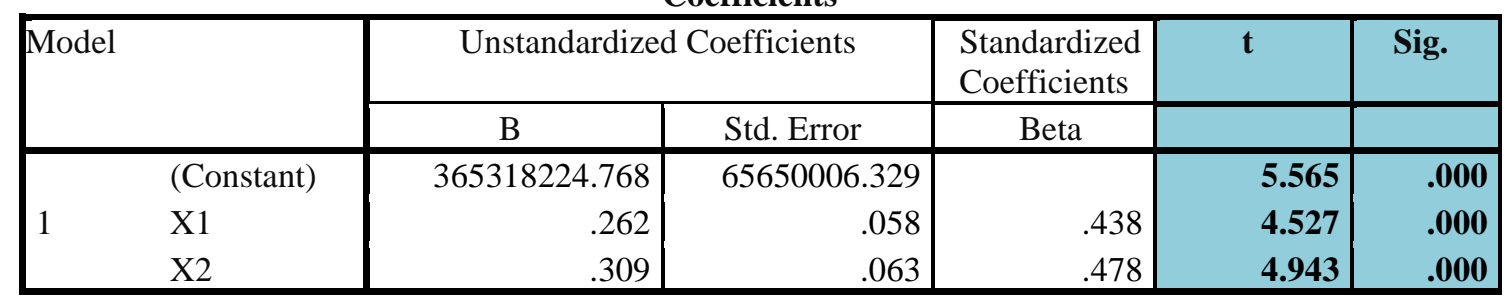

a. Dependent Variable: Y

Sumber: Output SPSS Versi 20 (2019)

Hasil dari Tabel 3 di atas menunjukkan bahwa $T_{\text {hitung }}$ yang diperoleh untuk variabel Kinerja Pemungutan Pajak Reklame $\left(\mathrm{X}_{1}\right)$ sebesar 4.527 dan signifikan sebesar 0.000. Hal ini menunjukkan $\mathrm{T}_{\text {hitung }}=\mathbf{4 . 5 2 7}>\mathrm{T}_{\text {Tabel }}=$ 1.65521 atau signifikan kecil dari 0.05 , maka Hipotesis Pertama dalam penelitian ini diterima yaitu Kinerja Pemungutan Pajak Reklame $\left(\mathrm{X}_{1}\right)$ berpengaruh secara signifikan terhadap Pendapatan Asli Daerah (Y) di Kota Batam.

Dan $\mathrm{T}_{\text {hitung }}$ yang diperoleh untuk variabel

Pungutan Retribusi Pajak Reklame $\left(\mathrm{X}_{2}\right)$ sebesar 4.943 dan signifikan sebesar 0.000. Hal ini menunjukkan $\mathrm{T}_{\text {hitung }}=4.943>\mathrm{T}_{\text {Tabel }}=$ 1.65521 atau signifikan kecil dari 0.05 , maka Hipotesis Kedua dalam penelitian ini diterima yaitu Pungutan Retribusi Pajak Reklame $\left(\mathrm{X}_{2}\right)$ 


\section{Terakreditasi Nasional}

\section{Available Online at: http://ejournal.upbatam.ac.id/index.php/jim}

berpengaruh secara signifikan terhadap dalam model mempunyai pengaruh secara Pendapatan Asli Daerah (Y) di Kota Batam. simultan terhadap variabel terikat. Berikut ini Hasil Uji F

Uji statistik $F$ digunakan untuk mengetahui hasil uji statistik F dapat ditunjukan pada tabel apakah semua variabel bebas yang dimasukkan 4.

Tabel 4 Hasil Uji F

ANOVA ${ }^{a}$

\begin{tabular}{|l|c|r|r|c|c|}
\hline Model & Sum of Squares & Df & Mean Square & F & Sig. \\
\hline Regression & 5919450361874383900.000 & 2 & 2959725180937191900.000 & $\mathbf{6 4 . 9 5 4}$ & $\mathbf{. 0 0 0}^{\mathbf{b}}$ \\
Residual & 2597294786625620500.000 & 57 & 45566575203958256.000 & & \\
Total & 8516745148500004900.000 & 59 & & & \\
\hline
\end{tabular}

a. Dependent Variable: Y

b. Predictors: (Constant), X2,X1

Sumber: Output SPSS Versi 20 (2019)

Sesuai dari Tabel 4 diatas menunjukkan bahwa Fhitung $=64.954>$ FTabel $=3.06$ (lihat pada Tabel distribusi F) dan signifikan $=0.000<$ 0.05, maka Hipotesis Ketiga dalam penelitian ini diterima yaitu Kinerja Pemungutan Pajak Reklame (X1) dan Pungutan Retribusi Pajak Reklame (X2) berpengaruh secara signifikan terhadap Pendapatan Asli Daerah (Y) di Kota Batam.

\section{KESIMPULAN}

Penelitian ini ingin menguji Kinerja Pemungutan dan Retribusi Pungutan Pajak Reklame berpengaruh secara signifikan Pendapatan Asli Daerah (PAD) Kota Batam. Adapun beberapa kesimpulan penelitian ini adalah sebagai berikut:

1. Kinerja Pemungutan Pajak Reklame berpengaruh positif dan signifikan terhadap Pendapatan Asli Daerah di Kota Batam.

2. Pungutan Retribusi Pajak Reklame berpengaruh positif dan signifikan terhadap Pendapatan Asli Daerah di Kota Batam.

3. Kinerja Pemungutan Pajak Reklame dan Pungutan Retribusi Pajak Reklame secara bersama-sama memiliki pengaruh yang positif dan signifikan terhadap Pendapatan Asli Daerah di Kota Batam.

\section{DAFTAR PUSTAKA}

Fidel. (2010). Pajak Penghasilan Carofin Publising, Jakarta.

Ghozali, Imam. (2011). Aplikasi Analisis Multivariate Dengan Program IBM SPSS 19. (Edisi Kelima.) Semarang: Universitas Diponegoro.

Kuswanto, Hedy. (2012). Analisis FaktorFaktor Yang Mempengaruhi Kinerja
Sistem Informasi Akuntansi Pada PT. BPR Weleri Makmur Jawa Tengah. (Versi Elektronik). Jurnal STIE Dharmaputra. Diperoleh 05 Oktober 2012, dari http:// ejournal.stiedharmaputra-smg.ac.id.

Mardiasmo. (2013). Perpajakan Edisi Revisi, Andi Offset, Yogyakarta.

Nazir, Moh. (2014). Metode Penelitian. Cetakan Enam, Bogor: Penerbit Ghalia Indonesia.

Priyatno, Duwi. (2008). Mandiri Belajar SPSS - Bagi Mahasiswa dan Umum, Yogyakarta: Mediakom.

Sugiyono. (2014). Metode Penelitian Kuantitatif, Kualitatif, dan Kombinasi (Mixed. Methods). Bandung: Alfabeta.

Umar, Husein. (2010). Metode Penelitian Untuk Skripsi dan Tesis serta Bisnis. Edisi Kedua. Jakarta: Penerbit Raja Grafindo Persada.

Undang-undang Nomor 28 Tahun 2009 tentang Pajak Daerah dan Retribusi Daerah dan Peraturan Daerah Kota Batam Nomor 12 Tahun 2008 tentang pokok-pokok pengelolaan keuangan daerah, membawa paradigma baru dalam pengelolaan daerah.

Undang-undang Nomor 22 Tahun 1999 tentang Pemerintahan Daerah selanjutnya disingkat dengan sebutan UU No. 22/1999.

Undang-undang Nomor 18 Tahun 1987 tentang Pajak Daerah dan Retribusi Daerah selanjutnya disingkat dengan sebutan UU No. 18/1987. 
Available Online at: http://ejournal.upbatam.ac.id/index.php/jim

Undang-undang Nomor 34 Tahun 2000 tentang

Perubahan Atas Undang-undang Nomor 18 Tahun 1987 tentang Pajak Daerah dan Retribusi Daerah, selanjutnya disingkat dengan sebutan UU No. 34/2000.

Waluyo. B Ilyas, Wirawan. (2011). Perpajakan Indonesia, Buku 1 Edisi 10. Salemba Empat. Jakarta.

Wibowo, Agung Edy. (2012). Aplikasi Praktis SPSS Dalam Penelitian. Yogyakarta: Gava Media. 